\title{
Preclinical Investigation of the Functional Effects of Memantine and Memantine Combined with Galantamine or Donepezil
}

\author{
Diana S Woodruff-Pak*,', Michael J Tobia', Xilu Jiao', Kevin D Beck ${ }^{2,3}$ and Richard J Servatius ${ }^{2,3}$ \\ 'Department of Psychology, Temple University, Philadelphia, PA, USA; ²Department of Neurology and Neurosciences, New Jersey Medical School, \\ University of Medicine and Dentistry, Newark, NJ, USA; ${ }^{3}$ Department of Veterans Affairs, New Jersey Health Care System, Newark, NJ, USA
}

\begin{abstract}
Combinations of drugs approved to treat Alzheimer's disease (AD) were tested in older rabbits with delay eyeblink classical conditioning, a form of associative learning severely impaired in AD. In Experiment I ( $n=49$ rabbits), low doses (0.1, 0.5, I.0, and 0.0 (vehicle) mg/kg) of memantine ( $\mathrm{Namenda}^{\mathrm{TM}}$ ) were tested. These three doses neither improved nor impaired acquisition at a statistically significant level. The $0.5 \mathrm{mg} / \mathrm{kg}$ dose had the greatest effect numerically and did not cause sensitization or habituation in explicitly unpaired controls. In Experiment 2 ( $n=56$ ), doses of galantamine (Razadyne ${ }^{\mathrm{TM}} ; 3.0 \mathrm{mg} / \mathrm{kg}$ ) and donepezil (Aricept ${ }^{\mathrm{TM}} ; 0.75 \mathrm{mg} / \mathrm{kg}$ ) that had comparable magnitudes of cholinesterase inhibition were tested alone and in combination with $0.5 \mathrm{mg} / \mathrm{kg}$ memantine. Older rabbits treated with galantamine and with galantamine + memantine learned significantly better than vehicle-treated rabbits, but adding memantine did not improve learning over galantamine alone. Older rabbits treated with donepezil or a combination of memantine and donepezil did not learn significantly better than rabbits treated with vehicle. Galantamine has two mechanisms of action: mild cholinesterase inhibition and allosteric modulation of nicotinic acetylcholine receptors (nAChRs). When equated for cholinesterase inhibition, galantamine had significant efficacy in the eyeblink conditioning model system, but donepezil did not, indicating that modulation of nAChRs may be the mechanism that significantly ameliorates learning deficits in this model. In the absence of AD neuropathology in older rabbits, memantine had no efficacy alone or in combination with the other drugs.

Neuropsychopharmacology (2007) 32, 1284- 1294. doi: I0.1038/sj.npp. I 301259; published online 22 November 2006
\end{abstract}

Keywords: acetylcholinesterase (AChE) inhibition; aging; allosteric modulation; Alzheimer's disease; NMDA antagonist; nicotinic acetylcholine receptors ( $\mathrm{nAChRs)}$

\section{INTRODUCTION}

Acetylcholine neurotransmission plays a crucial role in learning and memory and has been the focus of pharmacological therapy for Alzheimer's disease (AD). The first four drugs approved by the Food and Drug Administration to treat memory impairment in mild to moderate $\mathrm{AD}$ were acetylcholinesterase (AChE) inhibitors that promoted acetylcholine's action at the synapse. Glutamate neurotransmission and its activation of alpha-amino-3-hydroxy-5-methyl4 -isoxazole propionic acid (AMPA) and $N$-methyl-D-aspartate (NMDA) receptors contribute to long-term memory storage, but glutamatergic hyperactivity is neurotoxic and plays a role in neurodegeneration. Drugs targeting NMDA receptors to block excitotoxicity are an additional focus of pharmacological therapy for $\mathrm{AD}$. A drug approved by the FDA to treat symptoms in severe $\mathrm{AD}$ is memantine, an

*Correspondence: Professor DS Woodruff-Pak, Department of Psychology, Temple University, I70I North 13th Street, Weiss Hall/ 6th floor, Philadelphia, PA 19|22, USA, Tel: + I 215204 1258, Fax: + I 215204 5539, E-mail: pak@temple.edu

Received 24 April 2006; revised 18 September 2006; accepted 25 September 2006 uncompetitive NMDA-receptor antagonist. The fact that drugs with different mechanisms of action are available to treat $\mathrm{AD}$ introduces the prospect of prescribing drug combinations to amplify drug efficacy. Evidence on combination therapy for $\mathrm{AD}$ is limited (Schmitt et al, 2004), although negative drug-drug interactions have not yet been observed in clinical studies (Dantoine et al, 2006; Enz and Gentsch, 2004). Cholinesterase inhibitors are approved for treatment during the early stages of disease onset and often continued as the disease progresses, whereas memantine is approved for treatment at later stages when dementia is present. In severely demented patients with AD (Mini-Mental State Examination scores of 5-14), who received stable doses of donepezil, the addition of memantine resulted in significantly better outcomes than placebo (Cummings et al, 2006; Tariot et al, 2004). The major aim of this study was to evaluate further combinations of drugs targeting $\mathrm{AD}$ with an animal model and a task, delay eyeblink classical conditioning, of demonstrated impairment in human patients diagnosed with AD (Solomon et al, 1991; Woodruff-Pak et al, 1990).

Disruption of the brain cholinergic system in AD links this dementing disease to the model system of eyeblink conditioning in mammals, including humans. Eyeblink 
conditioning impairment in AD may reflect medialtemporal lobe atrophy and associated central nervous system cholinergic dysfunction that occurs early in the disease progression. Disruption of acetylcholine neurotransmission in the septohippocampal system impairs learning of the conditioned eyeblink response in young (Harvey et al, 1983; Solomon et al, 1983; Woodruff-Pak et al, 1994a) and older rabbits (Pak et al, 2002). Data also indicate that NMDA receptor activity is involved in the acquisition of classically conditioned eyeblink responses (Chen and Steinmetz, 2000; Churchill et al, 2001; Thompson and Disterhoft, 1997). There are dramatic neurobiological and behavioral parallels between humans and other mammals in this simple form of associative learning called eyeblink classical conditioning, making this model system useful in preclinical research (Woodruff-Pak, 1995).

\section{Acetylcholinesterase Inhibitors and Eyeblink Classical Conditioning}

Pharmacologic therapies to preserve the action of a dwindling acetylcholine pool in the AD brain have focused on prolonging its presence at the synapse. The acetylcholine molecule is inactivated in a single step. AChE is an enzyme that breaks down acetylcholine into choline and acetic acid. Inhibition of AChE is equivalent to increasing the activity of acetylcholine. Drugs approved by the FDA as reversible AChE inhibitors for the treatment of $\mathrm{AD}$ include tacrine (a 4-aminopyridine derivative), donepezil (a benzylpiperidine derivative), and galantamine (a phenanthrene tertiary alkaloid). Rivastigmine (a carbamate derivative) is a 'pseudoirreversible' inhibitor. Of these compounds, galantamine is the only molecule approved in Europe with mechanisms of action that include both AChE inhibition and allosteric potentiating effects at the nicotinic acetylcholine receptor (nAChR). In the United States, galantamine is approved as having one mechanism of action, AChE inhibition. Galantamine is a relatively mild AChE inhibitor. For an equivalent magnitude of AChE inhibition to donepezil, 3-15 times as much galantamine must be administered (Geerts et al, 2005). Galantamine and donepezil have been tested previously in preclinical studies using eyeblink classical conditioning.

Four doses of galantamine were tested in the $750 \mathrm{~ms}$ delay eyeblink classical conditioning procedure, and a dose of $3.0 \mathrm{mg} / \mathrm{kg}$ enabled older rabbits to achieve learning criterion rapidly and to produce a very high percentage of conditioned responses (CRs) (Woodruff-Pak and Santos, 2000). In a second experiment, the effects of galantamine were examined in young and older rabbits (Woodruff-Pak et al, 2001). A dose of $3.0 \mathrm{mg} / \mathrm{kg}$ galantamine improved learning significantly in young and older rabbits. Not only did galantamine-treated younger rabbits achieve learning criterion in significantly fewer trials, the $3.0 \mathrm{mg} / \mathrm{kg}$ dose of galantamine enabled older rabbits to learn at the same rate as young vehicle-treated rabbits. Two other laboratories have also demonstrated the efficacy of galantamine in eyeblink classical conditioning using the trace conditioning procedure (Simon et al, 2004; Weible et al, 2004).

Donepezil was tested at doses of 0.3 and $3.0 \mathrm{mg} / \mathrm{kg}$ in retired breeder rabbits in the $750 \mathrm{~ms}$ delay procedure. A dose of $3.0 \mathrm{mg} / \mathrm{kg}$ donepezil improved acquisition of CRs significantly (Woodruff-Pak, 2001). Donepezil did not facilitate conditioning in the $750 \mathrm{~ms}$ delay procedure in young rabbits (Woodruff-Pak et al, 2003). The demonstrated efficacy of donepezil and galantamine each at a dose of $3.0 \mathrm{mg} / \mathrm{kg}$ suggests that the mechanism by which galantamine produces its therapeutic effect is something other than AChE inhibition, as its potency as a AChE inhibitor may be as much as 15 times weaker than that of donepezil.

\section{NMDA Receptor Antagonism and Eyeblink Classical Conditioning}

NMDA receptors are ligand gated and voltage sensitive to the most common excitatory neurotransmitter, glutamate. NMDA receptors are found throughout the brain, including the structures normally engaged in eyeblink classical conditioning. In the case of NMDA receptor affinity for memantine, there is relatively higher affinity in the cerebellum, the structure essential for eyeblink conditioning, than in forebrain regions (Bresink et al, 1995; Porter and Greenamyre, 1995). Memantine is a clinically welltolerated uncompetitive NMDA receptor antagonist with strong voltage dependency and rapid blocking/unblocking kinetics (Parsons et al, 1999). Mild glutamate toxicity to postsynaptic neurons is blocked by memantine at concentrations significantly lower than those concentrations that impair normal physiological function and synaptic plasticity. Such kinetics may allow memantine to block ongoing pathologic processes that involve chronic NMDA activation, while simultaneously permitting normal neurophysiologic brain functions (Lipton and Chen, 2004). Memantine treatment has been directed primarily toward $\mathrm{AD}$ and other senile dementias (Jain, 2000; Tariot et al, 2004), although additional therapeutic applications have been suggested for this drug (Parsons et al, 1999).

NMDA antagonism was first tested in the eyeblink classical conditioning model system with a potent noncompetitive antagonist, MK-801 (Robinson, 1993), and with a competitive antagonist, CGP-39551 (Servatius and Shors, 1996). Both studies used the delay eyeblink classical conditioning procedure, but MK-801 was tested in rabbits whereas CGP-39551 was tested in rats. In both cases, delay eyeblink classical conditioning was impaired. Mutant mice lacking subunits NR2A and NR2C of the NMDA receptor channel were tested in delay eyeblink classical conditioning, and mice lacking the NR2A (but not NR2C) subunits were impaired (Kishimoto et al, 1997). Based on the distribution of these NMDA receptor subunits, the investigators concluded that acquisition of the conditioned eyeblink response does not depend on NMDA receptors in the cerebellar cortex, but does depend on these receptors in hippocampus and/or deep cerebellar nuclei. NMDA receptor antagonists also impair trace eyeblink classical conditioning that is hippocampus dependent (Takatsuki et al, 2001; Thompson and Disterhoft, 1997).

One study using human subjects, eyeblink conditioning, and memantine was carried out in Germany (Schugens et al, 1997) where memantine has been approved for the treatment of neurological disorders since 1982. Sixteen men of a mean age of 34 years were administered one $30 \mathrm{mg}$ dose of memantine or placebo and classically conditioned 
$4 \mathrm{~h}$ later using the delay eyeblink conditioning procedure. There was significant impairment in the acquisition of CRs in the men treated with memantine. Verbal and visuospatial memory were not impaired at this dose, supporting the results of binding studies that indicated increased potency of memantine in the cerebellum (essential for eyeblink conditioning) as compared to the forebrain (essential for verbal and visuospatial memory).

Using doses of $0.01,0.05,0.1$, and $0.3 \mathrm{mg} / \mathrm{kg}$ MK- 801 in rats, Jackson et al (2004) found that the lowest dose increased firing rate of prefrontal cortical neurons and improved performance on spontaneous alternation performance. The investigators did not record from other regions of the brain, including the hippocampus with its abundant distribution of NMDA receptors. Hippocampal and prefrontal cortical neurons are of demonstrated involvement in eyeblink classical conditioning (McLaughlin et al, 2002; Takehara et al, 2004; Weible et al, 2000). Research by Jackson et al (2004) showing that low doses of a potent noncompetitive NMDA antagonist increased neuronal firing rate and improved behavioral performance suggest the potential for facilitation by NMDA antagonists.

The lowest dose of MK-801 administered to rabbits tested in delay eyeblink conditioning was $0.05 \mathrm{mg} / \mathrm{kg}$ (Robinson, 1993). A dose of $0.05 \mathrm{mg} / \mathrm{kg}$ MK-801 depressed precortical neuronal firing rate and impaired behavior in rats, whereas a dose of $0.01 \mathrm{mg} / \mathrm{kg}$ MK-801 was excitatory in rat prefrontal cortical neurons and improved learning (Jackson et al, 2004). A dose of $0.01 \mathrm{MK}-801 \mathrm{might}$ facilitate eyeblink conditioning as it facilitated behavioral performance. Also, the clinical results with memantine demonstrate cognitive facilitation by NMDA antagonism (Jain, 2000; Tariot et al, 2004). Memantine is significantly less potent than MK-801 (Wenk et al, 1995). Given that very low doses of the potent NMDA antagonist MK-801 as well as many doses of memantine facilitate learning, one aim of the present study was to identify a dose of memantine that would ameliorate, or at a minimum not impair acquisition in older rabbits in delay eyeblink classical conditioning.

The second aim was to determine the effect of combined doses of memantine and galantamine or donepezil. In rabbit, between four and eight times less donepezil is needed to achieve the same level of brain AChE inhibition (Geerts et al, 2005). We chose to use a dose of donepezil four times lower than the dose of galantamine to equate the two drugs for AChE inhibition. The effective (or nonimpairing) dose of memantine was combined with a dose of galantamine $(3.0 \mathrm{mg} / \mathrm{kg})$ effective in rabbits in eyeblink classical conditioning, and a dose of donepezil $(0.75 \mathrm{mg} / \mathrm{kg})$ with a relatively equal magnitude of $\mathrm{AChE}$ inhibition to galantamine.

\section{MATERIALS AND METHODS}

\section{Study Population: Rabbits}

A total of 105 specific pathogen-free (SPF) female retired breeder rabbits were tested in Experiments 1 and 2. Rabbits were purchased from Covance (Denver, PA). The mean age of rabbits was 26.3 months (SD 0.2), and the mean weight was $4.1 \mathrm{~kg}$ (SD 0.04). Rabbits were individually housed in stainless steel cages in temperature- and humidity-con- trolled rooms. They had ad libitum access to food and water during the experiment. The light/dark cycle was $12 / 12 \mathrm{~h}$. The Institutional Animal Care and Use Committee (IACUC) at Temple University approved research procedures used in this study.

\section{Study Procedures}

The $750 \mathrm{~ms}$ delay eyeblink classical conditioning procedure, used in previous studies of eyeblink classical conditioning testing efficacy of galantamine or donepezil, was used in the present study. Techniques were similar to published reports (eg Woodruff-Pak et al, 2001). The rabbits were adapted to Plexiglas restrainers and headpieces for $1 \mathrm{~h}$ on each of the two consecutive days following arrival at the animal facility. On the second day of adaptation, a local ophthalmic anesthetic (proparacaine hydrochloride) was applied to the left eye, so that a 6-0 nylon suture loop could be placed in the temporal margin of the nictitating membrane (NM). A $3-\mathrm{cm}^{2}$ patch of fur was also shaved from the rabbit's back in order to expose the skin where subcutaneous injections were administered.

The conditioning apparatus consisted of four separate sound-attenuating chambers, permitting four rabbits to be trained simultaneously. A speaker mounted to the wall of each chamber delivered a $1-\mathrm{kHz}, 85-\mathrm{dB}$ tone that was used as the conditioned stimulus (CS). The headpiece, affixed behind the rabbit's ears and under its muzzle, held a plastic tube to deliver 3 psi corneal-directed air puff unconditioned stimulus (US) and a minitorque potentiometer (San Diego Instruments, San Diego, CA) to measure the rabbit's NM/ eyeblink response. Elastic eyelid retractors kept the rabbit's eye open. The potentiometer was secured to the NM via a lever and the nylon suture loop. Analog output from the potentiometer was digitized, stored, and analyzed using an IBM PC-compatible system (Chen and Steinmetz, 1998). This system also controlled the timing and presentation of the stimuli. For all experiments, the intertrial interval was randomized and ranged between 20 and 30 s. A single session lasted approximately $45 \mathrm{~min}$ and consisted of 90 trials.

In the delay eyeblink conditioning procedure, the duration of the tone CS was $850 \mathrm{~ms}$, followed $750 \mathrm{~ms}$ after its onset by a $100-\mathrm{ms}$ US. The CS and US coterminated. The rabbits received 10 training sessions (5 days per week for 2 weeks, excluding weekends). In the explicitly unpaired procedure, rabbits received the same treatment as in the paired procedure, with the exception that the tone and the air puff were never paired. On each unpaired trial, rabbits received either a tone-alone presentation or an air puffalone presentation. Forty-five trials of each stimulus type were presented in a randomized format during each session.

Changes in the position of the NM detected by the potentiometer were processed and stored in 3-ms bins by the computer. The program recorded a response when the NM moved a minimum of $0.5 \mathrm{~mm}$. A CR was recorded if the response occurred between 25 and $750 \mathrm{~ms}$ after the onset of the CS. An unconditioned response (UR) was recorded if the response took place more than $750 \mathrm{~ms}$ after the onset of the CS. In both paradigms, CR and UR amplitudes were taken as a measure of response magnitude. A trial was eliminated if NM activity crossed the response threshold 
within $100 \mathrm{~ms}$ before the onset of the CS. The criterion for learning was defined as eight consecutive CRs in a block of nine trials, with at least $40 \%$ of all trials within a training session as CRs.

\section{Drugs}

Janssen Pharmacautica supplied galantamine. Memantine was purchased from Tocris Cookson, Inc. (Ellisville, MO, USA), and donepezil was purchased from A\&A Pharmachem Inc. (Ottawa, ON, Canada). Drugs were mixed into sterile saline vehicle so that all injections were at volumes of $1.0 \mathrm{ml} / \mathrm{kg}$. Subcutaneous (s.c.) injections were administered $15 \mathrm{~min}$ before behavioral training. Animal testers were not blind during drug administration, primarily to insure that the correct dose combinations were given to the appropriate rabbits. Testing equipment was completely automated, making it highly unlikely that animal testers' knowledge of drug type could have affected animals' performance.

\section{Research Design}

In Experiment 1, a total of 49 retired breeder rabbits in six groups were tested. Three groups of rabbits ( $n=8 /$ group) were administered doses of $0.1,0.5$, and $1.0 \mathrm{mg} / \mathrm{kg}$ memantine and tested in the paired $750 \mathrm{~ms}$ delay eyeblink conditioning procedure. A fourth group of rabbits received sterile saline vehicle $(n=8)$ and was tested in the paired conditioning procedure. Two additional groups of rabbits were treated in the explicitly unpaired condition with $0.5 \mathrm{mg} / \mathrm{kg}$ memantine $(n=7)$ or sterile saline vehicle $(n=10)$.

In Experiment 2, a total of 56 additional retired breeder rabbits in eight groups were tested. Two groups of rabbits ( $n=8$ /group) were administered doses of $3.0 \mathrm{mg} / \mathrm{kg}$ galantamine or $0.75 \mathrm{mg} / \mathrm{kg}$ donepezil and tested in the paired $750 \mathrm{~ms}$ delay eyeblink conditioning procedure. Two groups of rabbits ( $n=8$ /group) were given separate injections of $0.5 \mathrm{mg} / \mathrm{kg}$ memantine and $3.0 \mathrm{mg} / \mathrm{kg}$ galantamine or $0.5 \mathrm{mg} /$ $\mathrm{kg}$ memantine and $0.75 \mathrm{mg} / \mathrm{kg}$ donepezil and tested in the paired $750 \mathrm{~ms}$ delay eyeblink conditioning procedure. A fifth group of rabbits received sterile saline vehicle $(n=10)$ and was tested in the paired conditioning procedure. Two additional groups of rabbits ( $n=7 /$ group) were treated in the explicitly unpaired condition with $0.5 \mathrm{mg} / \mathrm{kg}$ memantine and $3.0 \mathrm{mg} / \mathrm{kg}$ galantamine or $0.5 \mathrm{mg} / \mathrm{kg}$ memantine and $0.75 \mathrm{mg} / \mathrm{kg}$ donepezil. Data from the control group treated with sterile saline vehicle and tested in the explicitly unpaired condition $(n=10)$ in Experiment 1 were used for the unpaired analyses in Experiment 2. All rabbits received two injections and an equal volume of solution. In the case of the groups with one dose of drug, the second injection was sterile saline vehicle.

\section{Acetylcholinesterase Assays in Plasma and Brain}

At 3 days after the tenth training session and drug administration, an 11th s.c. injection of the same drug combination, which the rabbit had been receiving, was administered. After a 30 min interval, the rabbit was secured in a restrainer, $2 \mathrm{ml}$ of blood was drawn from the ear vein, and the rabbit was killed with 1-2 $\mathrm{ml}$ of Pentobarbital injected i.v. The brain was immediately removed, and the cerebral cortex, hippocampus, and cerebellum were dissected and stored in separate containers at $-80^{\circ} \mathrm{C}$. Blood was centrifuged for $10 \mathrm{~min}$ at 3000 r.p.m. in an Eppendorf (Hamburg, Germany) 5702R centrifuge, and plasma was stored at $-80^{\circ} \mathrm{C}$. Brain and plasma for rabbits treated with $3.0 \mathrm{mg} / \mathrm{kg}$ galantamine or $0.75 \mathrm{mg} / \mathrm{kg}$ donepezil were shipped on dry ice from Philadelphia, PA to Newark, NJ overnight and analyzed for AChE. After results from these analyses were complete, brain and plasma of rabbits treated with combinations of $0.5 \mathrm{mg} / \mathrm{kg}$ memantine and $3.0 \mathrm{mg} / \mathrm{kg}$ galantamine or $0.75 \mathrm{mg} / \mathrm{kg}$ donepezil were shipped and analyzed for acetylcholinesterase.

Cholinesterase activity was assessed based on established methodology (Luine and McEwen, 1983). Cerebral cortex, hippocampus, and cerebellum sections $(0.5 \mathrm{~g}$ wet weight per animal per brain region) were homogenized in $1 \mathrm{ml}$ of $50 \mathrm{nM}$ Tris- $\mathrm{HCl}$ buffer ( $\mathrm{pH} 8.0$ ) and subsequently diluted for sampling 1:20 (cortex and cerebellum) and 1:50 (hippocampus) in Tris- $\mathrm{HCl}$ buffer. Plasma samples were diluted $1: 5$ in deionized $\mathrm{H}_{2} \mathrm{O}$. Samples $(10 \mu \mathrm{l})$ were combined with $50 \mu \mathrm{l}$ of $0.05 \mathrm{M} \mathrm{KH}_{2} \mathrm{PO}_{4}$ (pH 7.0), $20 \mu$ ldeionized $\mathrm{H}_{2} \mathrm{O}$, and $20 \mu \mathrm{l}\left[{ }^{3} \mathrm{H}\right]$ acetylcholine iodide $(5 \mu \mathrm{Ci} / \mathrm{ml})$ in $2.0 \mathrm{mM}$ acetylcholine iodide in $\mathrm{KH}_{2} \mathrm{PO}_{4}$. The samples are incubated for $30 \mathrm{~min}$ at room temperature; afterwards, $100 \mu \mathrm{l}$ stop solution $(1.0 \mathrm{M}$ chloroacetic acid, $2.0 \mathrm{M} \mathrm{NaCl}$, and $0.5 \mathrm{M}$ $\mathrm{NaOH}$ ) was added. Subsequent scintillation mixture (in 10\% isoamyl alcohol) was added and the resulting solution was incubated at $21^{\circ} \mathrm{C}$ for $30 \mathrm{~min}$ at room temperature before the reading of sample for beta radiation (Beckman LS6500). Brain samples were calculated in reference to protein content as determined by the Bradford method (Bradford, 1976).

\section{RESULTS}

\section{Experiment I-Identification of a Dose of Memantine that Does Not Impair Learning}

For the four groups of rabbits tested in paired $750 \mathrm{~ms}$ CS-US delay eyeblink classical conditioning, a 4 (drug dose) by 10 (training sessions) repeated measures analysis of variance (ANOVA) was carried out to compare performance of rabbits at three doses of memantine $(0.1,0.5$, and $1.0 \mathrm{mg} / \mathrm{kg})$ and sterile saline vehicle $(0.0 \mathrm{mg} / \mathrm{kg})$. There was a significant effect of training sessions, $F(9,252)=$ 35.92, $p<0.001$, but no significant effect of drug dose $(\mathrm{F}(3,28)=2.14, p=0.117)$ or drug dose by training sessions interaction $(\mathrm{F}(27,252)=1.20, p=0.237)$. These low doses of memantine did not interfere with acquisition, and the dose of $0.5 \mathrm{mg} / \mathrm{kg}$ memantine had the numerically greatest effect (Figure 1a).

Comparisons of two other dependent measures in the paired condition, CR amplitude and response latency, in separate 4 (drug dose) by 10 (training sessions) repeated measures ANOVAs yielded similar results. For each dependent measure, there was a significant effect of training sessions, $\mathrm{F}(9,252)=10.17, p<0.001$ for $\mathrm{CR}$ amplitude and $\mathrm{F}(9,252)=24.61, p<0.001$ for response latency. There was not a significant effect of group or group by training sessions interaction for either variable. A one-way ANOVA comparing the effect of trials to a learning criterion of eight 

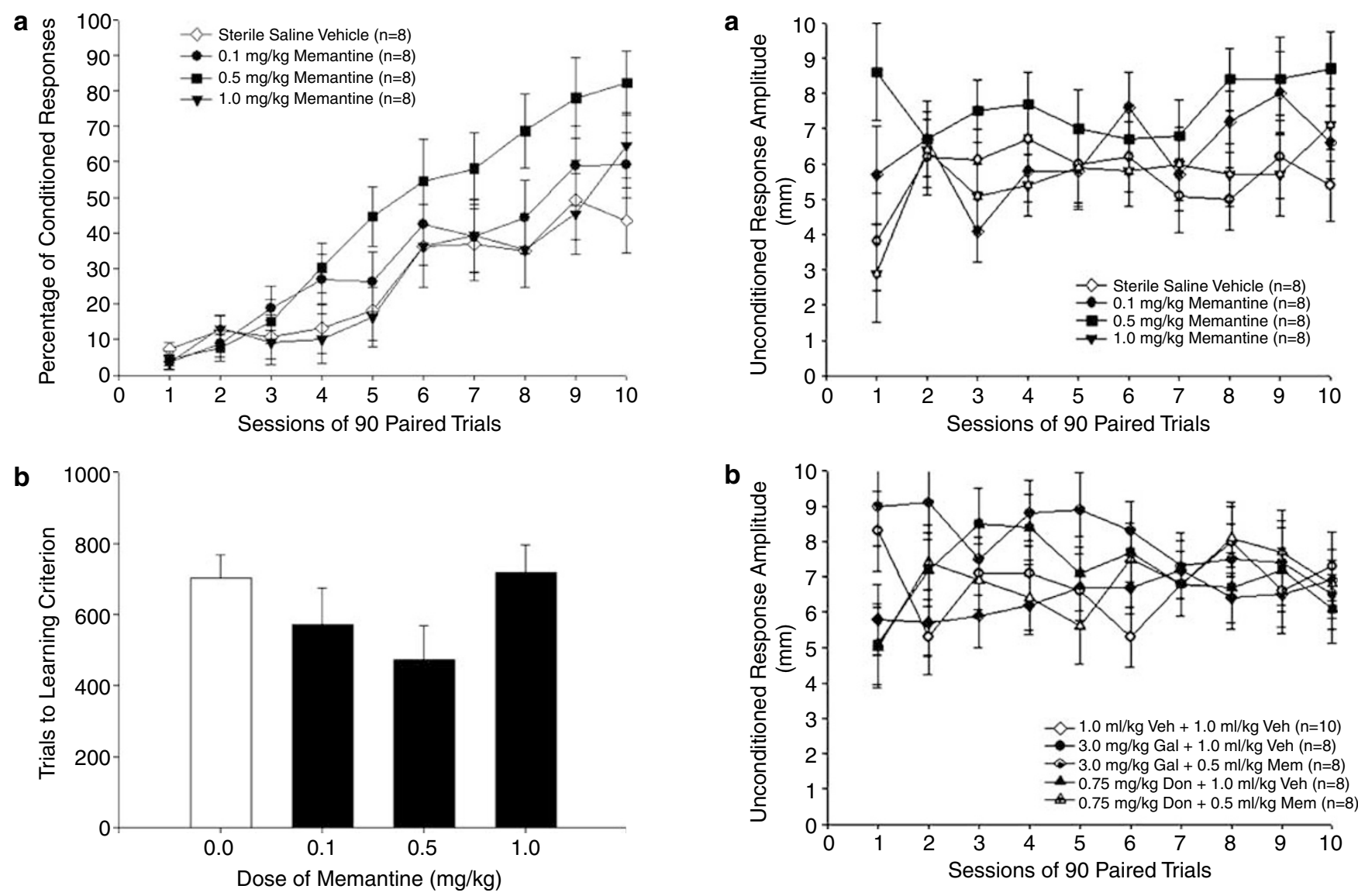

Figure I (a) Percentage of conditioned responses in 32 retired breeder rabbits tested with doses of $0.1,0.5,1.0 \mathrm{mg} / \mathrm{kg}$ memantine and vehicle for 10 sessions in the $750 \mathrm{~ms}$ delay eyeblink classical conditioning procedure. The effect of training sessions was statistically significant $(p<0.00 \mathrm{I})$, but the differences between rabbits treated with different doses of memantine did not attain statistical significance $(p=0.117)$. Error bars are standard error of the mean. (b) Trials to learning criterion in the same 32 retired breeder rabbits shown in (a) above. There was not a significant difference between the groups. Error bars are standard error of the mean.

CRs in nine consecutive trials in the paired condition did not attain significance at the 0.05 level of confidence, $\mathrm{F}(3,28)=1.82, p=0.167$ (Figure $1 \mathrm{~b}$ ).

A measure of the motor response to the air puff US is the magnitude of the UR. For the paired condition, a 4 (drug dose) by 10 (training sessions) repeated measures ANOVA on UR amplitude indicated a significant effect of training sessions, $\mathrm{F}(9,252)=2.021, p=0.037$ (Figure 2a). The effect of drug dose and the drug dose by training sessions interaction did not approach statistical significance.

For the explicitly unpaired condition, two measures were analyzed: Responses in the CS period (these responses are called CRs when the CS and US are paired, but they are simply random blinks or blinks to the CS itself in the explicitly unpaired condition) and UR amplitude. Responses in the CS period were analyzed in a 2 (drug dose $(0.5 \mathrm{mg} / \mathrm{kg}$ memantine, sterile saline vehicle $))$ by 10 (training sessions) repeated measures ANOVA. Neither the two main effects nor the interaction effect approached statistical significance. A similar 2 (drug dose) by 10 (training sessions) repeated measures ANOVA was carried

Figure 2 Unconditioned response (UR) amplitude in: (a) 32 retired breeder rabbits tested with doses of $0.1,0.5,1.0 \mathrm{mg} / \mathrm{kg}$ memantine and vehicle for 10 sessions in the 750 ms delay eyeblink classical conditioning procedure. The effect of training sessions was statistically significant $(p=0.037)$, but the effect of drug dose and the interaction effect were not significant. (b) Forty-two retired breeder rabbits tested with doses of $3.0 \mathrm{mg} / \mathrm{kg}$ galantamine, $3.0 \mathrm{mg} / \mathrm{kg}$ galantamine $+0.5 \mathrm{mg} / \mathrm{kg}$ memantine, $0.75 \mathrm{mg} / \mathrm{kg}$ donepezil, $0.75 \mathrm{mg} / \mathrm{kg}$ donepezil $+0.5 \mathrm{mg} / \mathrm{kg}$ memantine, and vehicle for 10 sessions in the $750 \mathrm{~ms}$ delay eyeblink classical conditioning procedure. There were no significant main effects of drug dose or training sessions, but the interaction between drug dose and training sessions was significant $(p=0.013)$. Error bars are standard error of the mean.

out on UR amplitude. Neither the two main effects nor the interaction effect approached statistical significance.

The goal of Experiment 1 was to identify a dose of memantine that ameliorated learning deficits in older rabbits or, at a minimum, a dose that did not impair learning. A dose of $0.5 \mathrm{mg} / \mathrm{kg}$ memantine met the latter criterion. The 0.5 dose of memantine did not cause sensitization or habituation of the eyeblink response in the unpaired control condition, and the motor response (UR) was not affected in the unpaired condition. The $0.5 \mathrm{mg} / \mathrm{kg}$ dose of memantine was used to test drug combination effects in Experiment 2.

\section{Experiment 2-Combined Effect of Memantine + Galantamine or Memantine + Donepezil}

Acetylcholinesterase levels. Doses of $3.0 \mathrm{mg} / \mathrm{kg}$ galantamine and $0.75 \mathrm{mg} / \mathrm{kg}$ donepezil were chosen to equate the two drugs for level of cholinesterase inhibition based on 
Table I Mean Plasma and Brain AChE Levels for Rabbits Treated with I I Daily Doses of 3.0 mg/kg Galantamine or 0.75 mg/kg Donepezil

\begin{tabular}{lcccc}
\hline Drug & $\begin{array}{c}\text { Plasma (nm/min/ml } \\
\text { protein) }\end{array}$ & $\begin{array}{c}\text { Cerebral cortex (nm/ } \\
\text { min/mg protein) }\end{array}$ & $\begin{array}{c}\text { Hippocampus (nm/ } \\
\text { min/mg protein) }\end{array}$ & $\begin{array}{c}\text { Cerebellum (nm/min/ } \\
\text { mg protein) }\end{array}$ \\
\hline $3.0 \mathrm{mg} / \mathrm{kg}$ Galantamine & $201.05(63.26)$ & $811.88(175.84)$ & $3303.21(322.04)$ & $1156.55(165.07)$ \\
$0.75 \mathrm{mg} / \mathrm{kg}$ Donepezil & $210.77(35.36)$ & $832.76(217.50)$ & $3018.03(500.2)$ & $1075.52(153.12)$ \\
\hline
\end{tabular}

previously reported assays (Geerts et al, 2005). Plasma AChE in rabbits treated with $3.0 \mathrm{mg} / \mathrm{kg}$ galantamine was a mean of $201.05 \mathrm{~nm} / \mathrm{min} / \mathrm{ml}$ (standard deviation $=63.3$ ), and in rabbits treated with $0.75 \mathrm{mg} / \mathrm{kg}$ donepezil was a mean of $210.77 \mathrm{~nm} / \mathrm{min} / \mathrm{ml}$ (standard deviation $=35.4$ ). A $t$-test indicated that the difference in plasma AChE levels did not approach statistical significance. A multivariate one-way ANOVA indicated that brain AChE levels in rabbits treated with $3.0 \mathrm{mg} / \mathrm{kg}$ galantamine were similar to AChE levels in rabbits treated with $0.75 \mathrm{mg} / \mathrm{kg}$ donepezil in cerebral cortex, hippocampus, and cerebellum (Table 1).

A multivariate one-way ANOVA was used to compare plasma and brain AChE levels for rabbits treated with $0.5 \mathrm{mg} / \mathrm{kg}$ memantine plus $3.0 \mathrm{mg} / \mathrm{kg}$ galantamine or $0.75 \mathrm{mg} / \mathrm{kg}$ donepezil. There was not a significant difference between the groups either in plasma AChE or brain AChE levels in cerebral cortex, hippocampus, or cerebellum.

Eyeblink classical conditioning. For the five groups of rabbits tested in paired $750 \mathrm{~ms}$ CS-US delay eyeblink classical conditioning, a 5 (drug dose) by 10 (training sessions) repeated measures ANOVA was carried out to assess the effect of various drug combinations on acquisition of CRs. The main effects of drug dose and training sessions were statistically significant, $\mathrm{F}(4,37)=4.66$, $p<0.001$ and $\mathrm{F}(9,333)=68.82, p<0.001$, respectively. The interaction between drug dose and training sessions was also significant, $\mathrm{F}(36,333)=1.59, p=0.020$ (Figure 3a). Post hoc analysis of the significant drug dose effect using the Tukey Honestly Significant Difference (HSD) test indicated that older rabbits treated with $3.0 \mathrm{mg} / \mathrm{kg}$ galantamine or with $3.0 \mathrm{mg} / \mathrm{kg}$ galantamine $+0.5 \mathrm{mg} / \mathrm{kg}$ memantine produced a higher percentage of CRs than vehicle-treated rabbits. These were the only two groups with a performance that was significantly better than rabbits treated with vehicle.

Comparisons of two other dependent measures in the paired condition, CR amplitude and response latency, in separate 5 (drug dose) by 10 (training sessions) repeated measures ANOVAs yielded a similar pattern of results. In the case of response latency, the main effects and interaction were significant. The effect of drug dose was $\mathrm{F}(4,37)=4.09, p=0.008$, the effect of training sessions was $\mathrm{F}(9,333)=59.57, p<0.001$, and the interaction between drug dose and training sessions was $\mathrm{F}(36,333)=1.74$, $p=0.007$. Post hoc analysis of the significant drug dose effect using the Tukey HSD test indicated that older rabbits treated with $3.0 \mathrm{mg} / \mathrm{kg}$ galantamine or with $3.0 \mathrm{mg} / \mathrm{kg}$ galantamine $+0.5 \mathrm{mg} / \mathrm{kg}$ memantine produced a shorter response latency than vehicle-treated rabbits. These were the only two groups with a performance that was significantly better than rabbits treated with vehicle.
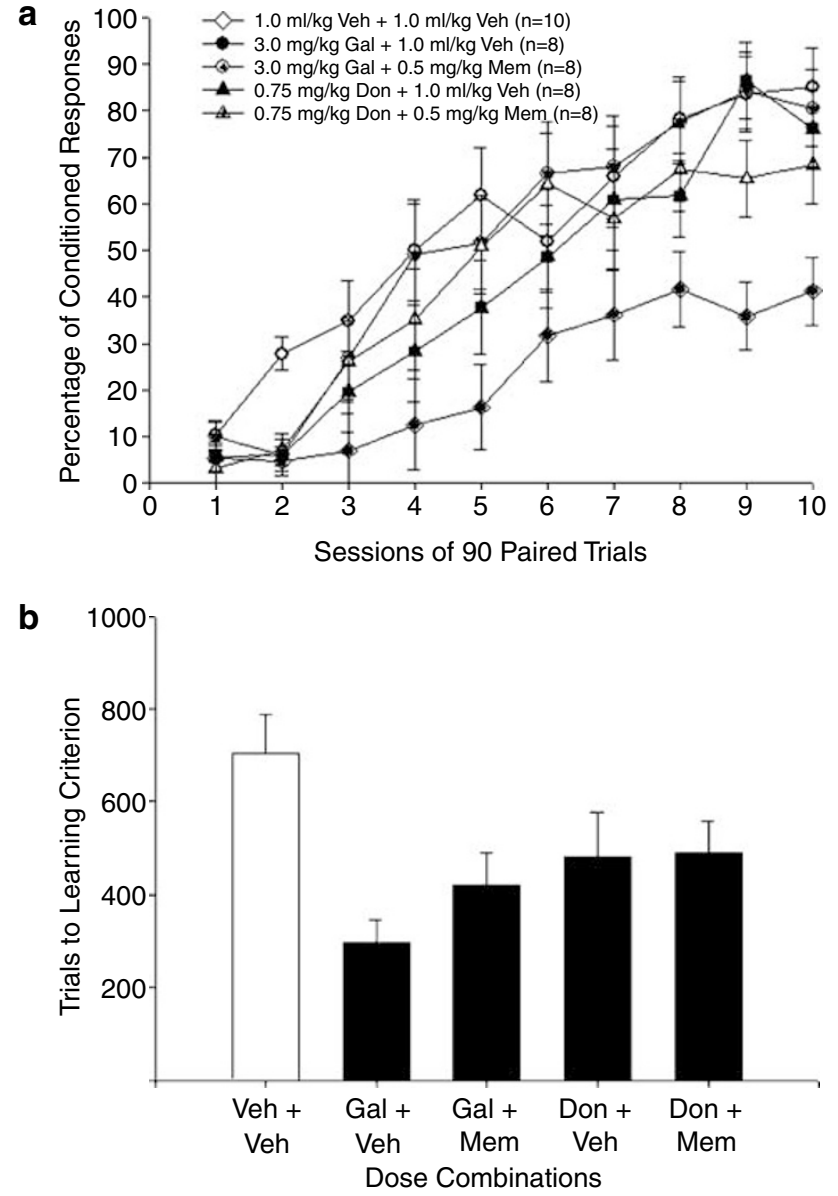

Figure 3 (a) Percentage of conditioned responses in 42 retired breeder rabbits tested with doses of $3.0 \mathrm{mg} / \mathrm{kg}$ galantamine, $3.0 \mathrm{mg} / \mathrm{kg}$ galantamine $+0.5 \mathrm{mg} / \mathrm{kg}$ memantine, $0.75 \mathrm{mg} / \mathrm{kg}$ donepezil, $0.75 \mathrm{mg} / \mathrm{kg}$ donepezil + $0.5 \mathrm{mg} / \mathrm{kg}$ memantine, and vehicle for 10 sessions in the $750 \mathrm{~ms}$ delay eyeblink classical conditioning procedure. The effect of drug dose, the effect of training sessions, and the interaction effect were statistically significant. Post hoc analysis of the significant drug dose effect indicated that doses of $3.0 \mathrm{mg} / \mathrm{kg}$ galantamine and $3.0 \mathrm{mg} / \mathrm{kg}$ galantamine $+0.5 \mathrm{mg} / \mathrm{kg}$ memantine produced significantly better learning than did vehicle. (b) Trials to learning criterion in the 42 retired breeder rabbits shown above. There was a significant effect of drug dose, and post hoc analysis indicated that $3.0 \mathrm{mg} / \mathrm{kg}$ galantamine resulted in significantly faster learning (fewer trials to criterion). Error bars are standard error of the mean.

In the case of CR amplitude, the drug dose effect did not attain significance at the 0.05 level of confidence, but the effect of training sessions and the drug dose by training sessions interaction effect were significant. The effect of drug dose was $\mathrm{F}(4,37)=2.45, p=0.063$, the effect of training sessions was $F(9,333)=23.59, p<0.001$, and the 
interaction between drug dose and training sessions was $\mathrm{F}(36,333)=1.51, p=0.034$.

A one-way ANOVA comparing the effect of trials to a learning criterion in the paired condition was significant, $\mathrm{F}(4,41)=3.98, p=0.009$ (Figure $3 \mathrm{~b}$ ). Post hoc Tukey HSD tests indicated that rabbits treated with $3.0 \mathrm{mg} / \mathrm{kg}$ galantamine had significantly fewer trials to learning criterion than vehicle-treated rabbits. None of the other groups were significantly different from the vehicle group in this post hoc test.

A measure of the motor response to the air puff unconditioned stimulus is the UR. In the paired condition, a 5 (drug dose) by 10 (training sessions) repeated measures ANOVA with the dependent measure of UR amplitude, there were no significant main effects, but the interaction between drug dose and training sessions was significant, $\mathrm{F}(36,333)=1.65, p=0.013$ (Figure 2b).

For the explicitly unpaired condition, responses in the CS period were analyzed in a 3 (drug dose $(3.0 \mathrm{mg} / \mathrm{kg}$ galantamine $+0.5 \mathrm{mg} / \mathrm{kg}$ memantine, $0.75 \mathrm{mg} / \mathrm{kg}$ donepezil $+0.5 \mathrm{mg} / \mathrm{kg}$ memantine, sterile saline vehicle)) by 10 (training sessions) repeated measures ANOVA. The effect of training sessions was significant, $F(9,189)=2.79$, $p=0.004$ (Figure 4). Post hoc comparisons in each of the 10 sessions indicated that none of the individual sessions were significantly different. The effect of drug dose and the interaction effect were not significant. For the explicitly unpaired condition, a similar 3 (drug dose) by 10 (training sessions) repeated measures ANOVA was carried out on UR amplitude, and neither of the two main effects nor the interaction effect approached statistical significance.

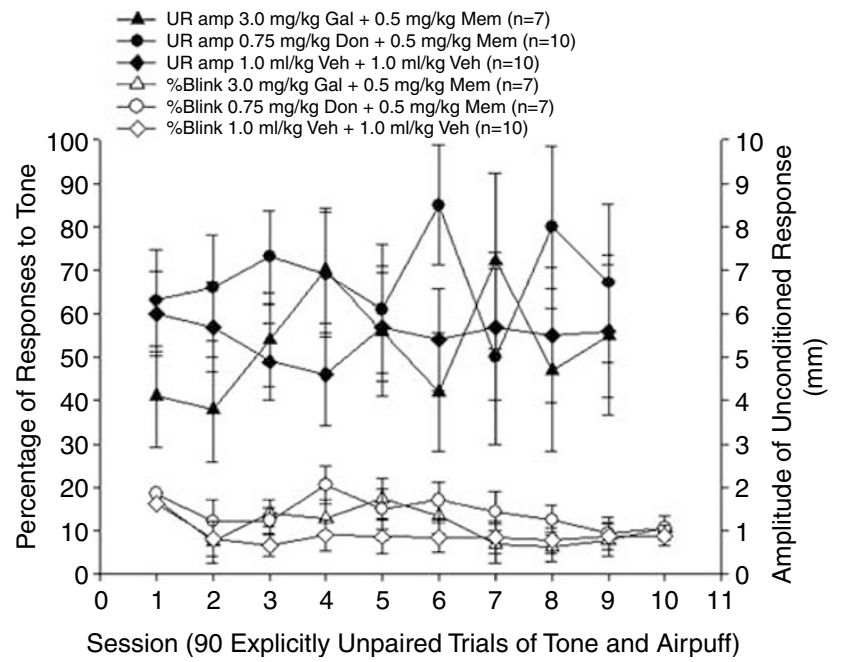

Figure 4 Responses to the tone conditioned stimulus (CS) in the period between 25 and $750 \mathrm{~ms}$ after tone CS onset (left ordinate) and unconditioned response (UR) amplitude (right ordinate) in 24 rabbits treated with $3.0 \mathrm{mg} / \mathrm{kg}$ galantamine $+0.5 \mathrm{mg} / \mathrm{kg}$ memantine, $0.75 \mathrm{mg} / \mathrm{kg}$ donepezil $+0.5 \mathrm{mg} / \mathrm{kg}$ memantine, and vehicle for 10 sessions tested in the explicitly unpaired condition. The effect of training sessions on responses to the tone CS was significant $(p=0.004)$. The effect of drug dose and the drug dose by training sessions interaction effect were not significant. There were no significant effects in the analysis of UR amplitude. Error bars are standard error of the mean.

\section{Combined Experiments 1 and 2: Drug Efficacy on Learning}

Percentage of CRs from paired CS-US $750 \mathrm{~ms}$ eyeblink classical conditioning in Experiment 1 on the $0.5 \mathrm{mg} / \mathrm{kg}$ dose of memantine was compared to percentage of CRs in Experiment 2 on $3.0 \mathrm{mg} / \mathrm{kg}$ galantamine or $0.75 \mathrm{mg} / \mathrm{kg}$ donepezil in a 3 (drug dose) by 10 (training sessions) repeated measures ANOVA. The main effects of drug dose and training sessions were significant, $\mathrm{F}(3,30)=5.76$, $p=0.003$ for drug dose, $\mathrm{F}(9,270)=48.92, p<0.001$ for training sessions. The interaction between drug dose and training sessions was also significant, $\mathrm{F}(27,270)=1.53$, $p=0.050$. Post hoc analysis of the significant drug dose effect using the Tukey HSD test indicated that older rabbits treated with $3.0 \mathrm{mg} / \mathrm{kg}$ galantamine produced a higher percentage of CRs than vehicle-treated rabbits (Figure 5). This was the only group with a performance that was significantly better than rabbits treated with vehicle. Similar results occurred in a comparison of trials to learning criterion in a one-way ANOVA. The effect of drug dose was statistically significant, $\mathrm{F}(3,30)=4.10, p=0.015$, and post hoc the Tukey HSD test indicated that the only drug dose resulting in significantly fewer trials to learning criterion was $3.0 \mathrm{mg} / \mathrm{kg}$ galantamine.

\section{DISCUSSION}

To evaluate the efficacy of combinations of FDA-approved drugs for the treatment of $\mathrm{AD}$, the effect of the NMDA antagonist, memantine on eyeblink classical conditioning was compared to and combined with two AChE inhibitors: galantamine and donepezil. In Experiment 1, three doses of memantine were tested in the $750 \mathrm{~ms}$ delay eyeblink conditioning procedure to identify a dose of memantine that improved or did not impair acquisition of CRs. A dose of $0.5 \mathrm{mg} / \mathrm{kg}$ memantine met those criteria and did not cause sensitization, habituation, or alterations in the motor

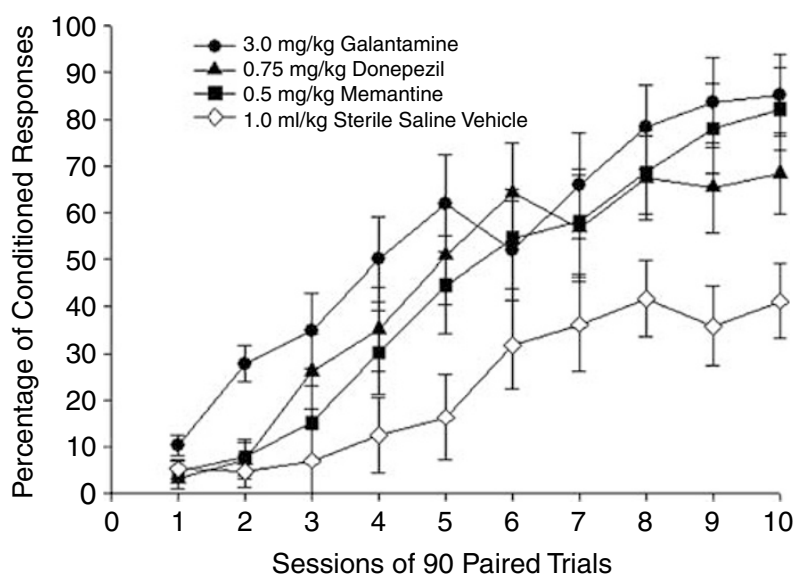

Figure 5 Mean total percentage of conditioned responses (CRs) over 10 training sessions in rabbits treated with $0.5 \mathrm{mg} / \mathrm{kg}$ memantine $(n=8)$, $3.0 \mathrm{mg} / \mathrm{kg}$ galantamine $(n=8), 0.75 \mathrm{mg} / \mathrm{kg}$ donepezil $(n=8)$, or sterile saline vehicle $(n=10)$. Rabbits treated with galantamine had significantly higher percentages of CRs in comparison to vehicle, and no other group was significantly different from vehicle. Error bars are standard error of the mean. 
response (UR). In Experiment 2, $0.5 \mathrm{mg} / \mathrm{kg}$ memantine was combined with doses of galantamine $(3.0 \mathrm{mg} / \mathrm{kg})$ and donepezil $(0.75 \mathrm{mg} / \mathrm{kg})$ equated for AChE inhibition. Galantamine and galantamine + memantine ameliorated impairment of acquisition of CRs in older rabbits above vehicle-treated levels. Donepezil and donepezil + memantine did not ameliorate impairment of acquisition of CRs in older rabbits above vehicle-treated levels. Adding memantine to galantamine or donepezil did not improve conditioning over acquisition with galantamine or donepezil alone. Comparisons of acquisition with a $0.5 \mathrm{mg} / \mathrm{kg}$ dose of memantine and $3.0 \mathrm{mg} / \mathrm{kg}$ galantamine, $0.75 \mathrm{mg} / \mathrm{kg}$ donepezil, and vehicle indicated that galantamine was the only drug that significantly improved acquisition of CRs and reduced the number of trials required for attainment of learning criterion in comparison to vehicle.

Using groups of eight to 10 rabbits yields high power in the eyeblink classical conditioning procedure. For the dependent measure of percentage of CRs, the observed power for the effect of training sessions was 1.0 for every analysis. The observed power for the interaction effects was above 0.9 in all cases, and the observed power for the group effect was 0.49 in Experiment 1, 0.92 in Experiment 2, and 0.92 for the comparison of galantamine, donepezil, and memantine. Thus, it was only in the comparison of groups treated with low and relatively similar doses of $0.1,0.5$, and $1.0 \mathrm{mg} / \mathrm{kg}$ memantine that the power was below 0.9 . The sample sizes used in these experiments have ample power to support the conclusions.

Our goal was to take advantage of the fact that drugs with different mechanisms of action are available to treat $\mathrm{AD}$ by examining in a preclinical model the prospect of prescribing drug combinations to amplify drug efficacy. Previously we demonstrated that some drug combinations do act synergistically (Woodruff-Pak et al, 2004). However, the nootropic (nefiracetam) and cholinesterase inhibitor/nicotinic allosteric modulating (physostigmine) drugs we combined have not been approved for treatment in human patients with $\mathrm{AD}$. Using FDA-approved drugs for the treatment of $\mathrm{AD}$ in the model system of eyeblink classical conditioning in rabbits, we observed no synergy with combinations of memantine and galantamine or donepezil. Nevertheless, these combinations merit additional exploration. Rationales for combinations of drugs affecting the cholinergic and glutamatergic systems are persuasive (Geerts and Grossberg, 2006; Grossberg et al, 2006). Clinical trial comparisons of the addition of memantine or placebo to donepeziltreated patients with moderate to severe $\mathrm{AD}$ demonstrated a reduction in behavioral symptoms with memantine (Cummings et al, 2006; Tariot et al, 2004). Clearly, prospects for effective combinations of drugs that are available for the treatment of $\mathrm{AD}$ require additional exploration.

\section{Experiment I-Identification of a Dose of Memantine that Does Not Impair Learning}

Whereas NMDA receptor antagonism typically impairs learning, in some conditions learning can be improved. Using extremely low doses of an NMDA antagonist is one method that can be used to improve learning. For example, a very low dose of $\mathrm{MK}-801(0.01 \mathrm{mg} / \mathrm{kg})$ increased firing rate of prefrontal cortical neurons in rats and improved performance on a spontaneous alternation task (Jackson et al, 2004). It has also been shown that in animals with extremely poor learning ability, low doses of NMDA receptor antagonists can enhance learning (Mondadori et al, 1989). Introducing impairments in animals is another means to show improved learning with NMDA antagonists. Animals showing deficits in learning as a result of entorhinal cortex lesions showed improvement in spatial learning when administered memantine (Zajaczkowski et al, 1996).

In the present study, although older rabbits with moderately impaired eyeblink conditioning were used, no dose of memantine significantly improved acquisition of CRs over levels achieved by vehicle-treated older rabbits. Rabbits of a mean age of 26 months have demonstrated agerelated neuropathology in the hippocampus, including a decrease in hippocampal neuronal excitability (Power et al, 2002), and significant loss of hippocampal nAChRs (J-G Li, MA Lehr, L-Y Liu-Chen, DS Woodruff-Pak, unpublished data). This degree of neuropathology may be too limited to show a benefit of memantine. Furthermore, memantine may affect aspects of cognition such as attention and processing speed that are not assessed in delay eyeblink classical conditioning. In dual-task studies in young adult humans, manipulations of attention did not cause differences in acquisition of CRs in delay eyeblink classical conditioning (Papka et al, 1997).

The model system of eyeblink classical conditioning in older rabbits has been used as a preclinical test for cognition-enhancing drugs in part because of the parallels in older rabbits and humans in delay eyeblink classical conditioning. An additional rationale for the use of delay eyeblink conditioning in older rabbits for preclinical studies is the fact that delay eyeblink conditioning is severely impaired in AD (Solomon et al, 1991; Woodruff-Pak et al, 1990). Memantine is approved for use in the late stages of $\mathrm{AD}$, whereas eyeblink classical conditioning in older rabbits has proved useful in assessing drugs targeting the cholinergic system in mild to moderate AD. In this regard, the $\mathrm{AD}$ model rabbit created by increasing dietary cholesterol may be a better model for assessment of memantine's effects on learning. AD neuropathology (Ghribi et al, 2006; Sparks et al, 1994) as well as impaired eyeblink conditioning have been observed in this model (Sparks and Schreurs, 2003).

In pharmacological studies, to have a valid conclusion about effects on learning as assessed by the CR, the motor response, the UR, should not be affected by the drug. Drug dose did not affect UR amplitude in the paired conditioning data, but there was a significant difference in UR amplitude over training sessions (Figure 2a). In Session 1, rabbits in the 0.1 and $1.0 \mathrm{mg} / \mathrm{kg}$ memantine groups had significantly lower UR amplitudes, introducing large variability in UR amplitude. Mean UR amplitude varied from $2.9 \mathrm{~mm}$ at the $1.0 \mathrm{mg} / \mathrm{kg}$ dose to $8.6 \mathrm{~mm}$ at the $0.5 \mathrm{mg} / \mathrm{kg}$ dose. As shown in Figure 1, CR percentage for the same rabbits was extremely low and not variable in Session 1. Mean CR amplitude for the four groups also had a narrow range, from $0.19 \mathrm{~mm}$ at the $0.1 \mathrm{mg} / \mathrm{kg}$ dose to $0.31 \mathrm{~mm}$ for vehicle-treated rabbits. In the explicitly unpaired condition, the effect of $0.5 \mathrm{mg} / \mathrm{kg}$ memantine on UR amplitude was no different from the effect of vehicle. We attribute the significant difference in 
UR amplitude over training sessions to high variability of the rabbits in Experiment 1 on the first day of training. This variability was reduced over subsequent training sessions. Variability in UR amplitude in Session 1 that resulted in the significant effect of UR amplitude over training sessions cannot account for the acquisition curves of percentage of CRs (shown in Figure 1a) and CR amplitude over the 10 training sessions.

\section{Experiment 2-Combined Effect of Memantine + Galantamine or Memantine + Donepezil}

As mentioned in regard to UR amplitude data in Experiment 1 , to have a valid conclusion about effects on learning, as assessed by the CR, the motor response, the UR, should not be affected by the drug. In Experiment 2, the analysis of UR amplitude in the paired condition yielded a significant interaction effect of drug dose and training sessions. There were no significant main effects of drug dose or training sessions in this analysis of UR amplitude. Like UR amplitude in Session 1 of Experiment 1, there was large variability of UR amplitude in Session 1 of Experiment 2. UR amplitude in Session 1 ranged from $5.0 \mathrm{~mm}$ in the $0.75 \mathrm{mg} / \mathrm{kg}$ donepezil $+0.5 \mathrm{mg} / \mathrm{kg}$ memantine group to $9.0 \mathrm{~mm}$ in the $3.0 \mathrm{mg} / \mathrm{kg}$ galantamine $+0.5 \mathrm{mg} / \mathrm{kg}$ memantine groups. As can be seen in Figure $2 \mathrm{~b}$, over training sessions the groups with higher UR amplitude lowered their mean UR amplitude, and the groups with lower UR amplitude increased mean UR amplitude so that by Session 10 the values were quite similar. Whereas there was a wide range in UR amplitude in Session 1, the range of percentage of CRs was narrow in Session 1 (Figure 3a). Mean CR amplitude had a range of $0.19 \mathrm{~mm}$ - ranging from 0.14 in the vehicle group to 0.33 in both the $3.0 \mathrm{mg} / \mathrm{kg}$ galantamine and $0.75 \mathrm{mg} / \mathrm{kg}$ donepezil $+0.5 \mathrm{mg} / \mathrm{kg}$ memantine groups. As with Experiment 1, we interpret the significant drug dose by training sessions interaction in UR amplitude in Experiment 2 to excessive variability with a UR amplitude range of $4.0 \mathrm{~mm}$ in Session 1 that was reduced to a very narrow range of $1.24 \mathrm{~mm}$ by Session 10 .

In the explicitly unpaired condition, there was a significant effect of training session for responses to the tone CS. However, post hoc analyses of the significant effect indicated that none of the group differences were significant on a given session. For all three drug doses, responses to the tone were generally in the $10 \%$ eyeblink response range that is the range for spontaneous blinking in rabbits.

The cognition-enhancing efficacy of $3.0 \mathrm{mg} / \mathrm{kg}$ galantamine in older rabbits tested with eyeblink classical conditioning has been replicated in this research along with the result that galantamine combined with memantine has an ameliorating effect. Both $3.0 \mathrm{mg} / \mathrm{kg}$ galantamine and $3.0 \mathrm{mg} / \mathrm{kg}$ galantamine $+0.5 \mathrm{mg} / \mathrm{kg}$ memantine yielded superior performance over vehicle-treated rabbits in terms of acquisition of CRs. However, the magnitude of cognition enhancement resulting from $3.0 \mathrm{mg} / \mathrm{kg}$ galantamine was not significantly changed by the addition of $0.5 \mathrm{mg} / \mathrm{kg}$ memantine. The number of trials to learning criterion (the speed or rate of learning) was reduced significantly by $3.0 \mathrm{mg} / \mathrm{kg}$ galantamine, but not by any other drug or drug combination.
A dose of $0.75 \mathrm{mg} / \mathrm{kg}$ donepezil did not improve learning significantly over vehicle in older rabbits in this study, although a dose of $3.0 \mathrm{mg} / \mathrm{kg}$ donepezil improved learning in older (Woodruff-Pak, 2001) but not younger rabbits (Woodruff-Pak et al, 2003). Higher levels of AChE inhibition provided by the $3.0 \mathrm{mg} / \mathrm{kg}$ donepezil dose apparently ameliorate learning deficits in older rabbits. The addition of $0.5 \mathrm{mg} / \mathrm{kg}$ memantine did not significantly affect the efficacy of $0.75 \mathrm{mg} / \mathrm{kg}$ donepezil. A dose of $0.5 \mathrm{mg} /$ $\mathrm{kg}$ memantine had a nonsignificant effect on learning in older rabbits, and it did not improve learning over the effect of $3.0 \mathrm{mg} / \mathrm{kg}$ galantamine or $0.75 \mathrm{mg} / \mathrm{kg}$ donepezil when it was combined with them.

In rabbits, AChE inhibition is four to eight times greater in donepezil than it is in galantamine (Geerts et al, 2005), and consequently the $0.75 \mathrm{mg} / \mathrm{kg}$ dose of donepezil was selected as it was four times lower than the effective dose of $3.0 \mathrm{mg} / \mathrm{kg}$ galantamine. In this regard, we replicated the Geerts et al (2005) analyses as plasma and brain AChE levels were similar for rabbits treated with $3.0 \mathrm{mg} / \mathrm{kg}$ galantamine or $0.75 \mathrm{mg} / \mathrm{kg}$ donepezil. Further, there was no difference in plasma and brain AChE levels in rabbits treated with combinations of $0.5 \mathrm{mg} / \mathrm{kg}$ memantine and $3.0 \mathrm{mg} / \mathrm{kg}$ galantamine or $0.75 \mathrm{mg} / \mathrm{kg}$ donepezil. This is the first study in which we attempted to equate galantamine and donepezil for AChE inhibition, and a lower dose of donepezil appeared to have less efficacy in older rabbits. Previously, we demonstrated that a dose of $3.0 \mathrm{mg} / \mathrm{kg}$ donepezil ameliorated learning impairment in older rabbits (Woodruff-Pak, 2001). A dose of $0.75 \mathrm{mg} / \mathrm{kg}$ donepezil equated in level of AChE inhibition to $3.0 \mathrm{mg} / \mathrm{kg}$ galantamine (Geerts et al, 2005) does not improve acquisition of CRs. With an equal level of $\mathrm{AChE}$ inhibition to that of donepezil, galantamine significantly improved learning-possibly with galantamine's second mechanism of action: allosteric modulation of nAChRs. Currently we are testing the hypothesis that nAChR activation is associated with cognition enhancement by measuring $\mathrm{nAChR}$ binding in various brain sites after drug administration and behavioral testing. Drugs being tested include galantamine, targeted nAChR agonists, and drugs such as donepezil that are not nAChR agonists.

Given that cholinesterase inhibition alone in $0.75 \mathrm{mg} / \mathrm{kg}$ donepezil does not ameliorate learning impairment in older rabbits, galantamine's allosteric activation of nAChRs may be the mechanism through which learning is affected in this animal model. Evidence for an allosteric modulation mechanism in galantamine and physostigmine was provided in electrophysiological studies (Pereira et al, 1994). Activation of muscle-type nAChRs by galantamine and nicotinic agonists indicated that galantamine interacted with a binding site that was distinct from the site for nicotinic agonists (Akk and Steinbach, 2005). Allosteric potentiation of nAChR currents by galantamine was transduced in downstream cellular responses to $\mathrm{nAChR}$ activation, including increases in intracellular $\mathrm{Ca}^{2+}$ and $\left[{ }^{3} \mathrm{H}\right]$ noradrenaline release (Dajas-Bailador et al, 2003).

Testing human $\alpha 7 \mathrm{nAChRs}$ expressed in Xenopus oocytes, it was demonstrated that memantine inhibits the function of these receptors (Maskell et al, 2003). In cultured hippocampal neurons, memantine also caused a concentrationdependent reduction of the amplitudes of whole-cell 
currents evoked by $\alpha 7$ nAChRs, and in this study memantine was more potent in inhibiting $\alpha 7$ nAChRs than NMDA receptors (Aracava et al, 2005). Blockade of $\alpha 7$ nAChRs by memantine may have decreased its efficacy in the model system of eyeblink classical conditioning. An antagonist to nAChRs, mecamylamine, significantly impaired eyeblink classical conditioning in young rabbits (Woodruff-Pak et al, 1994a), and a partial agonist of $\alpha 7$ nAChRs, GTS-21, improved eyeblink conditioning in older rabbits (Woodruff-Pak et al, 1994b).

The three drugs approved to treat $\mathrm{AD}$ tested in this study can be placed on a continuum in terms of their effect on $\alpha 7$ nAChRs. Galantamine, a mild cholinesterase inhibitor, allosterically modulates nAChRs, including $\alpha 7 \mathrm{nAChRs}$. Donepezil, a cholinesterase inhibitor with four to eight times the potency of galantamine, has no demonstrated allosteric effect on $\alpha 7 \mathrm{nAChRs}$ (eg Dajas-Bailador et al, 2003). Memantine, an NMDA antagonist also blocks $\alpha 7$ nAChRs (eg Aracava et al, 2005; Maskell et al, 2003). Galantamine and donepezil were equated for cholinesterase inhibition, and galantamine was the only drug to show a significant amelioration of learning impairment in older rabbits. It is possible that this amelioration occurred as a consequence of galantamine's allosteric modulation of nAChRs.

\section{ACKNOWLEDGEMENTS}

We thank Max Chae, Sung Kim, Laura Scarlota, and Sue Seta for their contributions to this study, including rabbit behavioral testing and data input and analysis. Portions of this work were supported by a grant from Janssen/OrthoMcNeil and AG21925 from the NIH.

\section{REFERENCES}

Akk G, Steinbach JH (2005). Galantamine activates muscle-type nicotinic acetylcholine receptors without binding to the acetylcholine-binding site. J Neurosci 25: 1991-2001.

Aracava Y, Pereira EFR, Maelicke A, Albuquerque EX (2005). Memantine blocks $\alpha 7^{\star}$ nicotinic acetylcholine receptors more potently than $\mathrm{N}$-Methyl-D-aspartate receptors in rat hippocampal neurons. J Pharmacol Exp Ther 312: 1195-1205.

Bradford MM (1976). A rapid and sensitive method for the quantitation of microgram quantities of protein utilizing the principle of protein-dye binding. Anal Biochem 72: 248-254.

Bresink I, Danysz W, Parsons CG, Mutschler E (1995). Different binding affinities of NMDA receptor channel blockers in various brain regions - indication of NMDA receptor heterogeneity. Neuropsychopharmcology 34: 533-540.

Chen G, Steinmetz JE (1998). A general-purpose computer system for behavioral conditioning and neural recording experiments. Behav Res Meth Instr Comput 30: 384-391.

Chen G, Steinmetz JE (2000). Intra-cerebellar infusion of NMDA receptor antagonist AP5 disrupts classical eyeblink conditioning in rabbits. Brain Res 887: 144-156.

Churchill JD, Green JT, Voss SE, Manley E, Steinmetz JE, Garraghty PE (2001). Discrimination reversal conditioning of an eyeblink response is impaired by NMDA receptor blockade. Integr Physiol Behav Sci 36: 62-74.

Cummings JL, Schneider E, Teriot PN, Graham SM, Memantine MEM-MD-02 Study Group (2006). Behavioral effects of memantine in Alzheimer disease patients receiving donepezil treatment. Neurology 67: 57-63.
Dajas-Bailador FA, Heimala K, Wonnacott S (2003). The allosteric potentiation of nicotinic acetylcholine receptors by galantamine is transduced into cellular responses in neurons: $\mathrm{Ca} 2+$ signals and neurotransmitter release. Mol Pharmacol 64: 1217-1226.

Dantoine T, Auriacombe S, Sarazin M, Becker H, Pere JJ, Bourdeix I (2006). Rivastigmine monotherapy and combination therapy with memantine in patients with moderately severe Alzheimer's disease who failed to benefit from previous cholinesterase inhibitor treatment. Int J Clin Pract 60: 110-118.

Enz A, Gentsch C (2004). Co-administration of memantine has no effect on the in vitro or ex vivo determined acetylcholinesterase inhibition of rivastigmine in the rat brain. Neuropharmacology 47: 408-413.

Geerts H, Grossberg GT (2006). Pharmacology of acetylcholineserase inhibitors and $N$-methyl-D-aspartate receptors for combination therapy in the treatment of Alzheimer's disease. J Clin Pharmacol 46: 8S-16S.

Geerts H, Guillaumat P-O, Grantham C, Bode W, Anciaux K, Sachak S (2005). Brain levels and acetylcholinesterase inhibition with galantamine and donepezil in rats, mice, and rabbits. Brain Res 1033: 186-193.

Ghribi O, Larsen B, Schrag M, Herman MM (2006). High cholesterol content in neurons increases BACE, $\beta$-amyloid, phosphorylated tau levels in rabbit hippocampus. Exp Neurol 200: 460-467.

Grossberg GT, Edwards KR, Zhao O (2006). Rationale for combination therapy with galantamine and memantine in Alzheimer's disease. J Clin Pharmacol 46: 17S-26S.

Harvey JA, Gormezano I, Cool-Hauser VA (1983). Effects of scopolamine and methylscopolamine on classical conditioning of the rabbit nictitating membrane response. J Pharmacol Exp Ther 225: 42-49.

Jackson ME, Homayoun H, Moghaddam B (2004). NMDA receptor hypofunction produces concomitant firing rate potentiation and burst activity reduction in the prefrontal cortex. Proc Natl Acad Sci USA 101: 8467-8472.

Jain KK (2000). Evaluation of memantine for neuroprotection. Expert Opin Invesg Drugs 9: 1397-1406.

Kishimoto Y, Kawahara S, Kirino Y, Kadotani H, Nakamura Y, Ikeda M, Yoshioka T (1997). Conditioned eyeblink response is impaired in mutant mice lacking NMDA receptor subunit NR2A. Neuroreport 8: 3717-3721.

Lipton SA, Chen HS (2004). Paradigm shift in neuroprotective drug development: clinically tolerated NMDA receptor inhibition by memantine. Cell Death Differ 11: 18-20.

Luine VN, McEwen BS (1983). Sex differences in cholinergic enzymes of diagonal band nuclei in the rat preoptic area. Neuroendocrinology 36: 475-482.

Maskell PD, Speder P, Newberry NR, Bermudez I (2003). Inhibition of human alpha 7 nicotinic acetylcholine receptors by open channel blockers of $\mathrm{N}$-methyl-D-aspartate receptors. $\mathrm{Br} \mathrm{J}$ Pharmacol 140: 1313-1319.

McLaughlin J, Powell DA, White JD (2002). Characterization of the neuronal changes in the medial prefrontal cortex during jaw movement and eyeblink Pavlovian conditioning in the rabbit. Behav Brain Res 132: 117-133.

Mondadori C, Weiskrantz L, Buerki H, Petschke F, Fagg GE (1989). NMDA receptor antagonists can enhance or impair learning performance in animals. Exp Brain Res 75: 449-456.

Pak JT, Green JT, Heifets B, Pak MH, Woodruff-Pak DS (2002). Nefiracetam ameliorates associative learning impairment in the scopolamine-injected rabbit. Med Sci Monitor 8: $105-112$.

Papka M, Ivry RB, Woodruff-Pak DS (1997). Eyeblink classical conditioning and awareness revisited: results of a dual-task study. Psycholog Sci 8: 404-408.

Parsons CG, Danysz W, Quack G (1999). Memantine is a clinically well tolerated $N$-methyl-D-aspartate (NMDA) receptor 
antagonist - a review of preclinical data. Neuropharmacology 38: 735-767.

Pereira EF, Alkondon M, Reinhardt S, Maelicke A, Peng X, Lindstrom J et al (1994). Physostigmine and galantamine: probes for a novel binding site on the alpha 4 beta 2 subtype of neuronal nicotinic acetylcholine receptors stably expressed in fibroblast cells. J Pharmacol Exp Ther 270: 768-778.

Porter RHP, Greenamyre JT (1995). Regional variations in the pharmacology of NMDA receptor channel blockers: implications for therpeutic potential. J Neurochem 64: 614-623.

Power JM, Wu WW, Sametsky E, Oh MM, Diserhoft JF (2002). Age-related enhancement of the slow outward calcium-activated potassium current in hippocampal CA1 pyramidal neurons in vitro. J Neurosci 22: 7234-7243.

Robinson GB (1993). MK801 retards acquisition of a classically conditioned response without affecting conditioning-related alterations in perforant path-granule cell synaptic transmission. Psychobiology 21: 253-264.

Schmitt B, Bernhardt T, Moeller HJ, Heuser I, Frolich L (2004). Combination therapy in Alzheimer's disease: a review of current evidence. CNS Drugs 18: 827-844.

Schugens MM, Egerter R, Daum I, Schepelmann K, Klockgether T, Loschmann PA (1997). The NMDA antagonist memantine impairs classical eyeblink conditioning in humans. Neurosci Lett 224: 57-60.

Servatius RJ, Shors TJ (1996). Early acquisition but not retention of the classically conditioned eyeblink response is $N$-methyl-Dasparatate (NMDA) receptor dependent. Behav Neurosci 110: $1040-1048$.

Simon BB, Knuckley B, Powell DA (2004). Galantamine facilitates acquisition of a trace-conditioned eyeblink response in healthy, young rabbits. Learn Mem 11: 116-122.

Solomon PR, Levine E, Bein T, Pendlebury WW (1991). Disruption of classical conditioning in patients with Alzheimer's disease. Neurobiol Aging 12: 283-287.

Solomon PR, Solomon SD, Vander Schaaf E, Perry HE (1983). Altered activity in the hippocampus is more detrimental to classical conditioning than removing the structure. Science 220: 329-331.

Sparks DL, Scheff SW, Hunsaker III JC, Liu H, Landers T, Gross DR (1994). Induction of Alzheimer-like $\beta$-amyloid immunoreactivity in the brains of rabbits with dietary cholesterol. Exp Neurol 126: 88-94.

Sparks DL, Schreurs B (2003). Trace amounts of copper in water induce beta-amyloid plaques and learning deficits in a rabbit model of Alzheimer's disease. Proc Natl Acad Sci USA 100: 11065-11069.

Takatsuki K, Kawahara S, Takehara K, Kishimoto Y, Kirino Y (2001). Effects of the noncompetitive NMDA receptor antagonist MK-801 on classical eyeblink conditioning in mice. Neuropharmacology 41: 618-628.

Takehara K, Kawahara S, Munemoto Y, Kuriyama H, Mori H, Mishina $\mathrm{M}$ et al (2004). The $N$-methyl-D-asparate (NMDA)type glutamate receptor GluRepsilon2 is important for delay and trace eyeblink conditioning in mice. Neurosci Lett 364: 43-47.

Tariot PN, Farlow MR, Grossberg GT, Graham SM, McDonald S, Gergel I, Memantine Study Group (2004). Memantine treatment in patients with moderate to severe Alzheimer's disease already receiving donepezil: a randomized controlled trial. JAMA 291: 317-324.

Thompson LT, Disterhoft JF (1997). Age- and dose-dependent facilitation of associative eyeblink conditioning by D-cycloserine in rabbits. Behav Neurosci 111: 1303-1312.

Weible AP, McEchron MD, Disterhoft JF (2000). Cortical involvement in acquisition and extinction of trace eyeblink conditioning. Behav Neurosci 114: 1058-1067.

Weible AP, Oh MM, Lee G, Disterhoft JF (2004). Galantamine facilitates acquisition of hippocampus-dependent trace eyeblink conditioning in aged rabbits. Learn Mem 11: 108-115.

Wenk GL, Danysz W, Mobley SL (1995). MK-801, memantine and amantadine show neuroprotective activity in the nucleus basalis magnocelluraris. Eur J Pharmacol 293: 267-270.

Woodruff-Pak DS (1995). Evaluation of cognition-enhancing drugs: utility of the model system of eyeblink classical conditioning. CNS Drug Rev 1: 107-128.

Woodruff-Pak DS (2001). Insights about learning in Alzheimer's disease from the animal model. In Carroll ME, Overmier JB (eds). Linking Animal Research and Human Psychological Health. American Psychological Association: Washington, DC. pp 323-336.

Woodruff-Pak DS, Ewers M, Shiotani T, Watabe S, Tanaka M, Wenk GL (2004). Nefiracetam and physostigmine: separate and combined effects on learning in older rabbits. Neurobio Aging 25: $807-816$

Woodruff-Pak DS, Finkbiner RG, Sasse DK (1990). Eyeblink conditioning discriminates Alzheimer's patients from nondemented aged. NeuroReport 1: 45-48.

Woodruff-Pak DS, Li Y-T, Kazmi A, Kem WR (1994a). Nicotinic cholinergic system involvement in eyeblink classical conditioning in rabbits. Behav Neurosci 108: 486-493.

Woodruff-Pak DS, Li Y-T, Kem WR (1994b). A nicotinic agonist (GTS-21), eyeblink classical conditioning, and nicotinic receptor binding in rabbit brain. Brain Res 645: 309-317.

Woodruff-Pak DS, Santos I (2000). Nicotinic modulation in an animal model of a form of associative learning impaired in Alzheimer's disease. Behav Brain Res 113: 11-19.

Woodruff-Pak DS, Vogel III RW, Wenk GL (2001). Galantamine: effect on nicotinic receptor binding, acetylcholinesterase inhibition, and learning. Proc Natl Acad Sci USA 98: 2089-2094.

Woodruff-Pak DS, Vogel III RW, Wenk GL (2003). Mecamylamine interactions with galantamine and donepezil: effects on learning, acetylcholinesterase, and nicotinic acetylcholine receptors. Neuroscience 117: 439-447.

Zajaczkowski W, Quack G, Danysz W (1996). Infusion of (+) -MK801 and memantine-contrasting effects on radial maze learning in rats with entorhinal cortex lesion. Eur J Pharmacol 296: $239-246$. 